e ISSN-0976-7223 | Visit Us - www.researchjournal.co.in

DOI : 10.15740/HAS/IJAE/7.2/378-383

\title{
Performance of drip irrigation on growth and development of horticultural crop at Ranwadi water shed
}

\section{A.R. MHASKE, S.M. TALEY AND V.P. UBARHANDE}

Received : 21.03.2014; Revised : 15.08.2014; Accepted : 30.08.2014

See end of the Paper for authors' affiliation

Correspondence to :

\section{A.R. MHASKE}

Department of Soil Water Conservation Engineering, College of Technology and Engineering, Dr. Panjabrao Deshmukh Vidyapeeth, AKOLA (M.S.) INDIA $\underline{\text { Email : mhaskear@gmail.com }}$
- ABSTRACT : The micro irrigation is one of the water saving method of irrigation being employed at large in various countries. Government of Maharashtra has given more emphasis to micro-irrigation system and adopting them on large scale to save water. Drip irrigation is a novel irrigation method in India. The advantage of drip irrigation is that liquid fertilizers can be added in the irrigation water. It also diminishes leaching of nutrients. The installation costs are too high for the production of most annual crops but the production of high value perennial crops is economically profitable. An experiment was conducted at Zonal Agricultural Research Station, Sindewahi, distt. Chandrapur, to study the performance of drip irrigation on growth and development of horticultural crops viz., mango, sapota and cashew nut at Ranwadi Water shed during the year 2002-03 to 2004-05. The result revealed the effect of drip irrigation treatment on growth and development of mango, sapota and cashew nut. It was found that the treatment 40 litres water day ${ }^{-1}$ plant $^{-1}$ through drip was found superior than all other other treatment in respect of height (30.33), canopy (1043) and diameter (2.92) stem of mango plant. In respect of sapota plant, treatment 60 litre waterday $^{-1}$ plant $^{-1}$ was found satisfactorily superior in respect of height (28.4), canopy (787) and diameter (2.82) stem of sapota plant. In respect of cashew nut plant the treatment 60 litre of water alternate day $^{-1}$ plant $^{-1}$ were found statistically significant and they were at par in case of height (33.70), canopy (1341) and diameter (3.18) stem of Cashew nut plant.

— KEY WORDS : Drip irrigation, Horticultural crop, Perennial crops, Canopy

— HOW TO CITE THIS PAPER : Mhaske, A.R., Taley, S.M. and Ubarhande, V.P. (2014). Performance of drip irrigation on growth and development of horticultural crop at Ranwadi water shed. Internat. J. Agric. Engg., 7(2) : 378-383. 